\title{
INDONESIA'S FINANCIAL LIBERALIZATION
}


The Institute of Southeast Asian Studies (ISEAS) was established as an autonomous organization in 1968. It is a regional research centre for scholars and other specialists concerned with modern Southeast Asia, particularly the many-faceted problems of stability and security, economic development, and political and social change.

The Institute is governed by a twenty-two-member Board of Trustees comprising nominees from the Singapore Government, the National University of Singapore, the various Chambers of Commerce, and professional and civic organizations. A ten-man Executive Committee oversees day-to-day operations; it is chaired by the Director, the Institute's chief academic and administrative officer.

The ASEAN Economic Research Unit is an integral part of the Institute, coming under the overall supervision of the Director, who is also the Chairperson of its Management Committee. The Unit was formed in 1979 in response to the need to deepen understanding of economic change and political developments in ASEAN. A Regional Advisory Committee, consisting of a senior economist from each of the ASEAN countries, guides the work of the Unit. 


\title{
INDONESIA'S FINANCIAL \\ LIBERALIZATION
}

\section{An Empirical Analysis of 1981-88 Panel Data}

\author{
Miranda S. Goeltom \\ Faculty of Economics, University of Indonesia
}


Published by

Institute of Southeast Asian Studies

Heng Mui Keng Terrace

Pasir Panjang

Singapore 0511

All rights reserved. No part of this publication may be reproduced, stored in a retrieval system, or transmitted in any form or by any means, electronic, mechanical, photocopying, recording or otherwise, without the prior permission of the Institute of Southeast Asian Studies.

(C) 1995 Institute of Southeast Asian Studies, Singapore

The responsibility for facts and opinions in this publication rests exclusively with the author and her interpretations do not necessarily reflect the views or the policy of the Institute or its supporters.

\section{Cataloguing in Publication Data}

Goeltom, Miranda S.

Indonesia's financial liberalization : an empirical analysis of 1981-88 panel data

(ISEAS current economic affairs series)

1. Finance--Indonesia.

2. Capital investments--Indonesia.

I. Title.

II. Series.

HG187 I5S61 1995 sls94-53930

ISBN 981-3016-87-6

ISSN 0218-2114

Typeset by International Typesetters

Printed in Singapore by Prime Packaging Industries Pte. Ltd. 
For the light of my life WINDA AND ERMANDA 
